Article

\title{
Comparative Scorecard Assessment of Urban Water Pricing Policies-The Case of Jordan and Iran
}

\author{
Mohammad Al-Saidi ${ }^{1, *(\mathbb{C} \text { and Sudeh Dehnavi }}{ }^{2}$ \\ 1 Center for Sustainable Development, College of Arts and Sciences, Qatar University, Doha P.O. Box 2713, Qatar \\ 2 Institute for Technology and Resources Management the Tropics and Subtropics, \\ TH-Köln-University of Applied Sciences, Betzdorfer Straße 2, 50679 Cologne, Germany; \\ sudeh.dehnavi@th-koeln.de \\ * Correspondence: malsaidi@qu.edu.qa
}

Received: 7 February 2019; Accepted: 2 April 2019; Published: 5 April 2019

\begin{abstract}
Urban water pricing is becoming increasingly important due to the rapid rate of urbanization and the expansion of water reclamation and reuse. The mounting evidence of failures of current pricing schemes makes analyzing their performance essential for understanding the adequacy of economic and sustainability policies in water management. However, urban water pricing policies are complex, serve multiple objectives, and vary widely across regions and countries. This paper presents an assessment framework for urban water pricing policies based on common conditions advocated for well-functioning pricing policies. Using a simplified scorecard, it compares the performance of urban water pricing policies in Jordan and Iran, two countries under growing scarcity pressure. Both countries show serious deficiencies with regard to the economic valuation of water services and the cost recovery of utilities. Public policies are rather oriented towards access and affordability, with Jordan showing a higher level of transparency and competition in tariff-setting. The assessment tool indicates a high potential for experience-sharing in future reforms, which should promote water as a scarce good. Such reforms need to prioritize full cost valuation, participation, and scientifically based designs of local and regional water tariffs.
\end{abstract}

Keywords: water prices; water sector performance; pricing assessment; full cost recovery; Iran; Jordan

\section{Introduction}

The demands on water pricing policies to achieve a multitude of often-conflicting goals of policymakers, utility managers, environmentalists and civil society seem impossible to satisfy. Water pricing is supposed to promote water as an economic good in line with the Dublin Principles for Water Management of 1992. Water pricing goals go beyond economic efficiency and include sustainability and equity, among many other objectives [1]. Water prices should also be transparent, legitimate, easy to administer, fair, etc. Some studies have stressed the prominence of the three objectives of economic efficiency, cost recovery, and social equity as a sort of umbrella of objectives [2-5]. For example, water scarcity can be addressed through economic full pricing, while the objectives of affordability and transparency can be understood as contributing factors to equity. However, on a local level, policymakers might pursue other objectives not related to scientific debates on pricing. Such a notion of the ambiguity and the controversial nature of water pricing objectives has often hindered the comparability of water pricing policies.

Furthermore, the academic literature includes a number of case studies on water pricing practices in different parts of the world, indicating a great variety of tariff structures and context-specificity of the performance of pricing policies. Many studies have examined the general objectives, experiences, and innovations in water pricing policies across countries [6-8], or focused on water 
prices in one subsector such as irrigation [9-11]. Nauges and van den Berg [12] compared 11 case studies and determined that cost performance, and hence the ideal pricing model, depends on economic development in general, and even on corruption perception or investment protection. Recent comparative studies confirm the notion about the heterogeneity of pricing policies and their performance. A study by the Organisation for Economic Co-operation (OECD) [13] emphasized the importance of tariffs that are tailored to local conditions. Accordingly, the practice of metering is unevenly adopted across OECD countries. Besides, environmental water charges such as abstraction charges, pollution/effluent charges, or water-use permits are emerging as a new kind of water tariff.

Due to the varying objectives and great heterogeneity in tariff structures on the local scale, the literature on water pricing has so far offered little means of assessing the overall performance of water pricing across countries. Dinar et al. [14] presented many country-level case studies with various types of water tariffs and policy innovations. They did not regard these case studies as 'best practices', nor did they provide any assessment method across the case studies. Instead, they pointed out some underlying trends such as the shift in water-pricing objectives from cost recovery and efficiency towards social and environmental considerations. Accordingly, water pricing is becoming a key issue across the globe due to increasing investment to achieve water security. Similarly, Zetland and Gasson [15], in their analysis of 308 cities in 102 countries, did not indicate in which locations water pricing policies are better-performing. Rather, they concluded that high water pricing levels correlate with overall country development factors such as higher GDP and better governance, but also with specific factors such as lower per capita consumption, smaller population, lower water availability, higher demand, and lower shortage risk.

Cross-country comparisons of local water tariffs rightly shy away from extrapolating one water pricing practice to other countries due to the high sensitivity of water pricing policies to local conditions. However, the focus on comparing concrete water tariffs does not allow us to know which countries exhibit better conditions for well-functioning water prices. Such knowledge has become increasingly important in order to assess reform potentials and risks to water security due to market-related failures. Similarly to comparing physical and economic water scarcity across countries, assessing and scoring water pricing practices across countries can provide valuable knowledge for action.

In order to provide useful comparative insights into water pricing policies, this paper focuses on the urban sector and carries out an assessment by using aggregated national-level data. The urban sector embodies retail pricing systems that allow for some comparisons on a utility, city, or national level. In fact, comparisons of utilities and cities are commonplace, mostly in developed countries and major cities [16-19]. This study develops one such simple assessment by focusing on conditions commonly propagated for urban water pricing policies to achieve key objectives such as efficiency, full cost recovery, and equity. The aim is to provide a structured and multi-objective assessment of urban pricing policies in Iran and Jordan through a simple but effective indicator-based scoring tool. In order to do this, the assessment is conceptually developed by relating urban water pricing to broad issues such as regulation, participation, and transparency that positively affect water pricing performance and help achieve contextuality of policies.

Using available national-level data, the proposed water pricing assessment will be illustrated by comparing Jordan and Iran, two water-scarce and developing countries in the Middle East with different conditions. Jordan is a smaller country (in 2017 around 40 billion USD GDP, 10 million inhabitants, and 91\% urbanization rate) than Iran (in the same year around 454 billion USD GDP, 81 million inhabitants, and $74 \%$ urbanization rate), while the level of water stress (freshwater withdrawals as a proportion of total renewable freshwater resources) stands at $119 \%$ and $90 \%$ in Jordan and Iran, respectively [20]. Jordan has been highlighted in recent literature due to multiple water problems such as groundwater depletion, transboundary water conflicts, and dependency on external water (e.g., [21]), but also due to the water governance reforms and the reorganization of the water supply sector [22]. There has been some criticism of urban water pricing policies in Iran for their shortcomings regarding financial and economic requirements [23]. Furthermore, in the capital city of 
Amman in Jordan, pricing policies can lead to a high burden on special population groups such as the poor $[24,25]$. However, we could not find a national-level study that assesses the different objectives of urban pricing policies in Jordan or Iran, or uses a comparison of the two countries. With regard to Iran, some literature has emerged on recent reforms of water subsidies [26], but the country remains a largely neglected case in urban water studies. At the same time, Iran is an important case due to the nowadays notable water stress in cities such as the capital city of Tehran [27], or the increased incidents of drought and water shortages across the country $[28,29]$.

\section{Demands on Urban Water Pricing Policies}

A comprehensive water pricing assessment at country level needs to fulfill a wide range of economic and social demands from policymakers. Here, we refer not to the choices of politicians for the price level but to the quality criteria used by well-intentioned policymakers to determine the price level. A water price also has to integrate the whole water value chain from abstraction, delivery, and consumption to caused externalities. Despite the differences in induced costs related to various use patterns, the best water pricing policy has to meet some basic policy requirements. In a large list of water pricing objectives, three are arguably the most important for policymakers: efficiency, cost recovery, and equity. They represent the three dominant perspectives on the merits of water prices, namely the economic view of maximizing society's welfare, the utilities' perspective of covering their costs, and the social perspective of making water affordable for the poor. These objectives have been widely used in the literature as the primary objectives to assess urban water pricing and often trade-offs in the policymaking of urban water pricing policies $[1-5,30]$. These trade-offs might not arise in practice, though. For example, in a hypothetical case of a water-scarce and economically well-off region, an efficient volumetric price according to full economic pricing would be high enough to cover the cost of utilities and be affordable, transparent, and equal for all, thus satisfying major equity concerns. However, policymakers might face trade-offs due to various reasons such as natural monopoly conditions or the prevalence of poverty. In such cases, the three objectives need to be understood and assessed on a case-by-case basis.

Economists argue that marginal cost pricing is the only pricing system that can achieve allocative efficiency: i.e., maximize the society's net benefits. In such a case, the water prices reflect the incremental costs caused by incremental demands by the people, since this constitutes the principle of marginality in modern economics. Any urban pricing policy therefore has to calculate marginal costs, which can include a variety of opportunity costs such as the marginal production cost, marginal user costs, and marginal environmental or external costs [31]. Economic efficiency does not necessarily contradict the second important goal of cost recovery of the utilities. Utility cost recovery has been the main practical concern of utilities in both developed and developing countries [5,30,32]. Water suppliers are commonly concerned about whether the water price can cover the average supply cost. For example, in the case of increasing water scarcity, the marginal costs are expected to be above the average cost, and there is thus no conflict between economic efficiency and cost recovery. However, if the supply cost is higher than marginal cost pricing, utilities make losses if they sell at marginal cost. This is the case with substantial fixed costs and economies of scale in water-abundant countries with little variable cost for water abstraction and delivery. Under these circumstances, two-part tariffs or decreasing block tariffs try to reconcile both goals of cost recovery and economic efficiency.

Affordability or equity represents another objective of water pricing that was addressed in few publications, confirming the conflictive nature of this objective to cost-recovery efforts of utilities or to neoliberal efficiency reforms [33-36]. Essentially, equity demands are inherently political and open to varying interpretations [37]. They can be achieved by many pricing designs such as increasing block tariffs (IBTs) or price discounts for the poor, which, however, require careful design in order not to have adverse effects such as subsidizing the non-poor [5,35]. Economists try to achieve the equity objective by modifying the welfare function of society to accommodate the concerns of certain groups 
or weak members [38]. However, proponents of equity advocate for water pricing to be used for the cross-subsidization of poor households by rich ones or state subsidies. This also corresponds to the notion of social equity, which sees water as a social good that needs to be guaranteed to everyone in a certain amount regardless of affordability [39]. However, some scholars point out to the welfare distortions of cross-subsidization through water prices and propose better alternatives for targeting the poor, namely through direct transfer and the social security system [40,41].

\section{Urban Water Pricing Scorecard Method}

\subsection{Scorecard Design and Indicators}

The pricing assessment proposed by this study uses a simple indicator-based scorecard that reflects the three above-mentioned pricing goals and the key conditions required to meet them. These conditions go beyond the exact structure of the water tariffs, although they do require basic design conditions of tariffs; e.g., metering, a certain price level, and simplicity. In developing the conceptual idea behind the assessment, the focus was on identifying the key factors or principles that can strengthen the performance of water pricing in a specific case study. Such key factors are sometimes not directly or exclusively related to the water pricing practice, but have a significant influence on its success.

Table 1 provides an overview of the objectives and indicators identified in the water pricing assessment, while Table 2 gives the scoring criteria. The first broad objective of economic efficiency is divided into the principles of marginal cost pricing, availability of economic regulation, and the use of instruments to promote competition. As explained earlier, economic efficiency implies marginal cost pricing. To achieve any volumetric price such as marginal cost pricing, meters are necessary. There have been a number of studies on the subject of metering. Results on the cost-benefit relationship of metering were inconclusive, but the marginal cost is identified as the key determinant of making metering worthwhile [42,43]. We assume, however, that universal metering is the correct means of pricing - in comparison to flat-rate systems - for a number of reasons. Firstly, metering is a prerequisite for economic efficiency in the case of increasing marginal cost. This is the case under water-scarcity conditions, but also in other cases as well. Freebairn [44] argues that this will increasingly be the case in many countries because of emerging 'expensive' water sources such as desalination, wastewater reuse, and water recycling. Besides, even with water abundance, marginal cost pricing calculations often ignore other opportunity costs related to environmental costs and externalities. If such costs are included in the cost-benefit analyses of metering, it can make metering worthwhile even in situations with high water abundancy. Furthermore, one can argue that climate change, or increasing water pollution, is going to make marginal costs higher than zero with increases in the future, making metering advisable for the majority of utilities across countries. In view of this, regardless of the specific decision of certain utilities on metering, metering as a wide pricing practice on a country level is scored positively.

Table 1. Objectives and indicators of the urban water pricing scorecard.

\begin{tabular}{|c|c|}
\hline Pricing Objectives and Principles & Indicator \\
\hline \multicolumn{2}{|l|}{ Efficiency } \\
\hline Marginal Cost E1a & Availability of volumetric pricing (metering) \\
\hline Marginal Cost E1b & Price level to water scarcity \\
\hline Economic Regulation E2 & Incentive-based economic regulation of water providers \\
\hline Competition E3 & Water markets and transfers \\
\hline \multicolumn{2}{|l|}{ Cost Recovery } \\
\hline Financial Viability C1a & Price level \\
\hline Financial Viability $\mathrm{C} 1 \mathrm{~b}$ & Collection Rate \\
\hline Commercialization $\mathrm{C} 2$ & Level of private-sector participation \\
\hline \multicolumn{2}{|l|}{ Equity } \\
\hline Affordability Q1 & Water expenditure relative to monthly household income \\
\hline Accessibility Q2 & Services coverage \\
\hline Transparency Q3 & Number of water tariff systems relative to price differentiation \\
\hline Participation Q4 & Level of decentralization \\
\hline
\end{tabular}


Table 2. Scoring grid of the water pricing assessment.

\begin{tabular}{|c|c|c|c|}
\hline Indicator & Low Performance (1 Point) & Moderate Performance (2 Points) & High Performance (3 Points) \\
\hline EI1a & Flat-rate pricing & Mixed system of metering and flat rates & $\begin{array}{l}\text { Universal metering used as } \\
\text { a pricing policy }\end{array}$ \\
\hline EI1b & $\begin{array}{c}\text { Comparatively low prices with } \\
\text { high level of water } \\
\text { scarcity/comparatively high } \\
\text { prices with high water availability }\end{array}$ & $\begin{array}{l}\text { Comparatively high prices, or low with } \\
\text { moderate level of water availability }\end{array}$ & $\begin{array}{l}\text { Comparatively high prices with } \\
\text { high level of water } \\
\text { scarcity/comparatively low prices } \\
\text { with high water availability }\end{array}$ \\
\hline EI2 & $\begin{array}{l}\text { No regulation of water utilities or } \\
\text { regulation using only } \\
\text { benchmarking }\end{array}$ & $\begin{array}{l}\text { A mixture of benchmarking regulation } \\
\text { and yardstick competition using } \\
\text { incentives and punishments in } \\
\text { selective cases }\end{array}$ & $\begin{array}{l}\text { Yardstick competition using } \\
\text { incentives and punishments as the } \\
\text { main form of utilities' regulation }\end{array}$ \\
\hline EI3 & No markets for urban bulk water & Bulk water markets in some regions & $\begin{array}{l}\text { Bulk water markets are widely } \\
\text { implemented }\end{array}$ \\
\hline $\mathrm{Cla}$ & $\begin{array}{l}\text { Average national water price in } \\
\text { the supply sector is below } 0.4 \\
\text { USD, or utilities do not cover } \\
\text { O\&M costs }\end{array}$ & $\begin{array}{l}\text { Average national water price in the } \\
\text { supply sector is between } 0.4 \text { and } 1 \text { USD, } \\
\text { while most utilities cover O\&M }\end{array}$ & $\begin{array}{c}\text { Average national water price in } \\
\text { the supply sector is above } 1 \text { USD } \\
\text { while most utilities cover O\&M } \\
\text { plus investment costs }\end{array}$ \\
\hline $\mathrm{C} 1 \mathrm{~b}$ & Collection rate below $80 \%$ & Collection rate between $80 \%$ and $95 \%$ & Collection rate of $95-100 \%$ \\
\hline $\mathrm{C} 2$ & $\begin{array}{l}\text { No significant participation of } \\
\text { private sector }\end{array}$ & $\begin{array}{l}\text { Forms of public-private partnerships } \\
\text { and private sector participation exist }\end{array}$ & $\begin{array}{l}\text { Active role of private sector } \\
\text { companies in service provision }\end{array}$ \\
\hline Q1 & $\begin{array}{l}\text { Water expenditure relative to } \\
\text { income is above } 10 \%\end{array}$ & $\begin{array}{l}\text { Water expenditure relative to income } \\
\text { is } 5-10 \%\end{array}$ & $\begin{array}{l}\text { Water expenditure relative to } \\
\text { income is less than } 5 \%\end{array}$ \\
\hline Q2 & Service coverage below $70 \%$ & Service coverage between 70 and $90 \%$ & Service coverage above $90 \%$ \\
\hline Q3 & $\begin{array}{l}\text { High number of tariffs nationwide } \\
\text { with big differences between } \\
\text { highest and lowest tariff }\end{array}$ & $\begin{array}{l}\text { High number of tariffs, but with no } \\
\text { significant price differentiation/high } \\
\text { price differentiation with moderate or } \\
\text { low number of tariffs }\end{array}$ & $\begin{array}{l}\text { Moderate number of tariffs with } \\
\text { no significant price differentiation }\end{array}$ \\
\hline Q4 & $\begin{array}{l}\text { National water providers with } \\
\text { high level of centralization }\end{array}$ & $\begin{array}{l}\text { Largely decentralized water utilities } \\
\text { still dependent (financially and } \\
\text { administratively) on national agencies }\end{array}$ & $\begin{array}{l}\text { Financially and administratively } \\
\text { independent local or regional } \\
\text { water utilities }\end{array}$ \\
\hline
\end{tabular}

Another element of marginal cost pricing is the relationship between average and marginal cost. For this indicator, the overall price level in a country is compared to water scarcity conditions. In this sense, countries with a high water scarcity level can justify high water prices in a global comparative perspective. A country with a decreasing marginal cost (e.g., high water abundance) should theoretically have lower prices than other countries. It is worth mentioning that marginal cost pricing is rarely used by water utilities due to natural monopoly conditions and the preference of utilities to use average cost pricing. Average cost pricing is easier to calculate using historical data, while marginal cost pricing is more difficult to determine since it should reflect full economic cost including (environmental) externalities and scarcity rents [5,30]. However, for our purpose of assessing the objective of economic efficiency, marginal cost pricing is essential. Furthermore, in the absence of a method to calculate marginal cost of all cities, the two indicators used-of metering and a reasonable relationship between price level and scarcity-are arguably the two important prerequisites for marginal cost pricing.

In addition to the aforementioned issues, the other two principles of economic regulation and competition investigate the existence of economic instruments to promote markets as the key to achieving economic efficiency. Instruments of economic regulation such as benchmarking and yardstick competition promote efficiency through incentives for the utilities to perform better. Benchmarking merely 'names and shames' utilities by forcing them to publish performance data. Yardstick competition sets clear incentives for utilities through regulating the price they can set, their budgets, or the awards allocated to them by the state. Such instruments are used by regulators across many countries and are particularly important for enforcing marginal cost pricing in the case of natural monopolies who tend to prefer average cost pricing. Benchmarking and yardstick regulation can help utilities learn from best practices, and adopt efficiency measures such as designing adequate tariffs of provided services that reflect long-term marginal cost $[45,46]$. Furthermore, with regard to competition, the indicator used is the availability of water bulk markets and water trading.

There are several arguments that trading in the wholesale markets can improve price signals and thus improve efficiency in urban water pricing. According to Chong and Sunding [47], trading water helps to equalize marginal prices faced by water users and to provide information about alternative 
uses. Similarly, Sibly and Tooth [48] argue that water markets improve competition in the urban sector, increase flexibility in the face of fluctuating demands, and ensure that price and capacity reflect (long-term) economic efficiency. Thus, although water markets can face many institutional challenges [49], their mere existence can be expected to reflect positively on the issue of efficient prices, particularly in the urban sector where competition for bulk supply is easier to bring about.

With regard to the second broad objective, that of cost recovery, the financial viability of the water providers is addressed by two indicators. Firstly, we look at the national water price and national cost recovery data. By considering the two, one can get an impression about cost recovery performance on utilities on an annual basis. For the price level, we use widely adopted thresholds in international comparisons. The benchmarks used of 0.4 USD (coverage of operation and maintenance (O\&M) costs), or 0.4-1.00 USD (O\&M plus most investment costs), and above 1 USD (O\&M plus investment costs in cases of extreme supply shortage), are based on the cross-city surveys of Global Water Intelligence (GWI) [50]. Optimally, the average national price to be investigated is based on data of billed price averages across utilities in order to encompass the actual consumption by different groups in the client base of the utilities. However, the thresholds used are usually conservative and might not reflect the current scarcity situation in some developing countries [2,51]. For example, some more recent surveys put the average unit price of water in Asia and Africa at less than 1 USD per cubic meter, while the average for all cities is double this threshold, and three times more for Europe [52]. In Europe, Article 9 of the Water European Framework Directive (WFD) foresees that all member states should allow for the adequate cost recovery water services, including environmental and resource costs. However, these demands remained controversial regarding the definition of water services and the adequacy of local cost recovery contributions [53], as well as the way to compare such full cost recovery across localities [54]. To address this, we also look into national cost recovery data, which indicates which costs are covered by most utilities. As an example of such an approach, on a national level, cost-recovery of water services by households is still not achieved in some European countries [53].

Another indicator used is the collection rate, which reflects how much of the utilities' revenues are collected, since this can negatively affect the overall cost recovery performance of utilities. For example, utilities might face huge financial problems in fragile states if consumers stop paying the bills (see [5]). Finally, the commercialization of utilities is considered as positive for cost recovery and is represented by an indicator of private sector participation. Here, private sector participation is defined using a scale from no participation in service provision, through partial participation via public-private partnerships (PPPs), to formal privatization of urban supply. PPPs need to cover the actual supply, whereby private companies take commercial risks, e.g., a lease of certain operations. The assumption is that private companies will only participate if they cover their costs, and thus positively contribute to the larger sectoral objective of cost recovery. In an extreme but unlikely case, most water utilities are privatized through long-term concessions and ownership transfer of hard assets, thus delegating commercial risk and financial independence in tariff-setting to the private sector. Evidence shows that private companies, despite being in some cases as good as or worse than public companies in regard to equity and efficiency, place a stronger emphasis on cost recovery (e.g. $[55,56])$.

The objective of equity can be achieved through the principles of affordability, service coverage, transparency, and participation. Firstly, affordability is a key element of any equitable pricing policy and relates to water expenditure and household income. Internationally, the benchmark of 3-5\% of monthly income for water-related expenses has been widely used (see [57]). Secondly, service coverage can lead to a negative impact on equity since unconnected, mostly poor, households usually pay a higher price by resorting to private vendors (see $[58,59])$. We assume here that there will always be some households left out of the network and service coverage, and so a $90 \%$ coverage rate can still be good. Whittington et al. [60] argue that poor households in developing countries might be better served through non-network technologies and still be covered by improved water and sanitation services. Thirdly, transparency is important for equity perception and acceptance of the tariff pricing. 
A country with a relatively high number of tariffs and big differences in price levels across cities and within tariff blocks can be perceived by consumers as having unjust or non-transparent water prices.

It is important to note that, in theory, such variations in prices can be justified by differences in marginal costs, and thus might not be negative per se. However, under the equity objective, such large variations need to be considered negatively on the basis of transparency and equality. Furthermore, some evidence shows that poor populations suffer from large inequalities in water prices that can arise from price differences related to ownership differences (private vs. public) of urban water utilities [61], or from the uneven application of free-market reforms in developing countries [62]. Finally, decentralization is seen as a way to increase participation in the water sector and deepen democracy and equity $[49,63]$. Besides, it helps achieve efficiency and performance, since utilities' decisions, like the right pricing policies, will be aligned to local conditions and customers' characteristics such as demand level or elasticity (e.g., [64,65]). Table 2 summarizes the indicators and scoring categories.

\subsection{Method Development and Data}

The theoretical and conceptual development of the scorecard with the above-explained indicators was carried out in 2016 as a semester-long, group exercise for a graduate class on water economics at TH-Köln, University of Applied Sciences, in Cologne, Germany. The initial round of scoring was carried out by two groups of students, who relied on diverse data sources (partially indicated in Table 3), but also on input from experts on water issues in the two countries from the Institute for Technology in the Tropics and Subtropics (ITT) in the same university. The scoring determinants in Table 3 represent the key investigated data in order to determine the indicator level based on the three performance categories in Table 2. The scoring of the two countries was presented and discussed at the end of the class till an agreement on scoring was reached. The scoring was later redone using more recent sources in late 2018, using the scoring process described in Table 3. The scoring process is iterative, i.e., the determinant are investigated in small steps after each other. For documenting evidence supporting the scoring, the primary data sources in Table 3 are used. Different sources were used to support a scoring of single indicators. Some data types (e.g., national water policies or survey of utilities) did not exist for both countries. Furthermore, we also relied on two categories of studies for certain data, namely water pricing studies, and studies on administrative and institutional aspects in the water sectors of both countries. However, such studies with up-to-date data are generally lacking. The Results section of this paper also uses other secondary literature to reference arguments that are used to evaluate a certain scoring determinant. Finally, we used expert input to validate scoring on institutional and policy related evaluations, i.e., determining the level regulation, commercialization, competition and transparency. While the scoring of these indicators was carried out based on literature, the scores converged with the provided experts' advice, who also provided some of the data and literature. Phone interviews were carried out only with two scholars in Iran, while other interviews were carried out at TH-Köln, which has a pool of experts, particularly from within a German-Arab master program on Integrated Water Resources Management with the German-Jordanian University in Amman, Jordan. 
Table 3. Scoring process and data sources.

\begin{tabular}{|c|c|c|c|c|}
\hline Indicator & $\begin{array}{c}\text { Scoring Determinants } \\
\text { (Successively Investigated) }\end{array}$ & Data Sources & & Description \\
\hline EI1a & $\begin{array}{l}\text { Urban pricing tariffs; Predominant } \\
\text { pricing practices }\end{array}$ & $a, b$ & \multirow{11}{*}{$\begin{array}{l}\text { (a) } \\
\text { (b) } \\
\text { (c) } \\
\text { (d) } \\
\text { (e) } \\
\text { (f) } \\
\text { (g) } \\
\text { (h) } \\
\text { (i) }\end{array}$} & \multirow{11}{*}{$\begin{array}{l}\text { National, cross-utility surveys: } \\
\text { Jordan [66], Iran [67] } \\
\text { National water policies: } \\
\text { Jordan [68] } \\
\text { FAO Aquastat: [69] } \\
\text { Global urban water pricing } \\
\text { surveys: [17-19,52] } \\
\text { Country-level water } \\
\text { governance review studies: } \\
\text { Jordan [22,24,70] } \\
\text { Water pricing studies: Jordan } \\
\text { [23,24] } \\
\text { World Bank data [20] } \\
\text { Water administration studies: } \\
\text { Jordan [25,71], Iran [26,27] } \\
\text { Expert input }\end{array}$} \\
\hline EI1b & $\begin{array}{l}\text { Average national urban water } \\
\text { prices; Water scarcity conditions } \\
\text { (cross-country comparisons on } \\
\text { renewable water availability per } \\
\text { capita); National price-to-price } \\
\text { levels in countries with similar } \\
\text { scarcity conditions }\end{array}$ & $a, c, d$ & & \\
\hline EI2 & $\begin{array}{l}\text { Economic regulation in the urban } \\
\text { water sector; Predominant urban } \\
\text { water regulation practices }\end{array}$ & $b, e, h, i$ & & \\
\hline EI3 & $\begin{array}{l}\text { Country-wide water trading } \\
\text { schemes for the urban sector }\end{array}$ & $b, e, h, i$ & & \\
\hline C1a & $\begin{array}{l}\text { Aggregated data on cost recovery of } \\
\text { urban water utilities; Average } \\
\text { national water tariffs if adequate } \\
\text { cost-recovery data not found }\end{array}$ & $\mathrm{a}, \mathrm{g}$ & & \\
\hline $\mathrm{C} 1 \mathrm{~b}$ & $\begin{array}{l}\text { Per city and national-level collection } \\
\text { rate data }\end{array}$ & $a, f$ & & \\
\hline $\mathrm{C} 2$ & $\begin{array}{l}\text { Incidents of private sector } \\
\text { participation in the urban water } \\
\text { sector; National data on } \\
\text { privatization in urban water supply }\end{array}$ & $b, e, h, i$ & & \\
\hline Q1 & $\begin{array}{l}\text { National client base date in the } \\
\text { urban sector, Water expenditure as } \\
\text { a percentage of income of different } \\
\text { client groups (e.g., \% of clients } \\
\text { having certain water } \\
\text { expenditure/income ratios) }\end{array}$ & $a, f$ & & \\
\hline Q2 & National service coverage data & $\mathrm{a}, \mathrm{g}$ & & \\
\hline Q3 & $\begin{array}{l}\text { Number of urban water tariffs; } \\
\text { Average water prices per city }\end{array}$ & $a, f$ & & \\
\hline Q4 & $\begin{array}{l}\text { Number of independent service } \\
\text { providers; Incidents of } \\
\text { corporatization and } \\
\text { decentralization reforms }\end{array}$ & $b, e, h, i$ & & \\
\hline
\end{tabular}

\section{Case Studies}

Water pricing policies in Jordan are typical of severely water-scarce countries with increasing marginal cost and pressures to improve, above all, efficiency and cost recovery. The current per capita supply in Jordan of around 145 cubic meters per year is expected to fall to 91 cubic meters per year by 2025, making this small country (around 10 million inhabitants) one of the most water-scarce countries worldwide [41]. Water pricing therefore plays an important role in facilitating future changes towards demand management and sustainable resource use. Its current performance on economic efficiency, cost recovery, and equity is assessed later only briefly.

Iran is now considered a water-scarce country with total renewable water resources per capita of 1732 cubic meters in 2014, declining from 2357 cubic meters in 1992, according to FAO Aquastat [69]. Estimates expect this figure to decrease below 1000 cubic meters in 2030, mainly due to an increase in population of $36 \%$ in the same period [72]. Climate change and higher temperatures represent additional factors affecting water availability [73], but there are other pressures, such as economic sanctions, that have fueled agricultural self-sufficiency policies and caused a de facto water bankruptcy [29]. Most parts of Iran have experienced a general dominant positive temperature trend, with the rate of change varying from 0.09 to $0.38{ }^{\circ} \mathrm{C}$ per decade during 1961-2010 [74]. Most of the water withdrawals were used in the agricultural sector $(92.18 \%$ ), with $1.17 \%$ in industry and $6.64 \%$ for municipal purposes [20], indicating the high importance of water regulations in the agricultural sector. 
For decades now, Iran's water policies have sought to foster the economic growth of industry and agriculture while providing basic water and sanitation services. Pricing policies as a tool to control water demand have been neglected in Iran for decades. Public policies have rather focused on water access using dams, extraction of groundwater, and new desalinization and water treatment plants-the latter representing a minor option due to the low treatment rates and structural difficulties [75]. By 2015, the total dam capacity of Iran increased to $32.24 \mathrm{~km}^{3}, 7.2$ times higher than in 1960, while desalinated water accounted for 0.2 million cubic meters in 2014 in comparison to only 0.003 in 1991, according to FAO Aquastat [69].

\section{Results}

\subsection{Scoring in Jordan and Iran}

\subsubsection{Economic Efficiency}

Table 4 presents the comparison overview (scorecard) and the indicator results. It also includes a summary of the justification for the comparative scoring for each indicator. On economic efficiency, results are mixed in both countries, with good performance only on metering (indicator E1a). In Jordan, universal metering is a state policy in both urban and agricultural sectors since the adoption of the National Water Strategy in 2009. Although the reduction in the very high water losses of around $50 \%$ [76] due to unreliable meters and illegal connections is still an issue, Jordan has made significant progress regarding the metering of household consumption, but also the licensing and metering of wells [77]. Jordan relies largely on groundwater resources. According to the National Water Strategy of 2016-2025, desalination and wastewater reuse are set to increase from $12.8 \%$ for wastewater reuse-desalination is currently non-existent-to around 34\% of the total use by 2025 [68]. The situation is similar in Iran. In light of the severe pressure on water supply, water pricing has recently been given more attention as an economic regulatory and allocative tool, with volumetric pricing as the universal pricing policy in the urban supply sector [67]. Furthermore, the use of alternative water sources such as treated wastewater and desalination is on the rise [75]. 
Table 4. Scoring grid of the water pricing assessment.

\begin{tabular}{|c|c|c|c|}
\hline Objective & Jordan & Iran & Summary of Justification \\
\hline Efficiency & 7 & 6 & $\begin{array}{l}\text { Jordan is slightly better-performing on this objective } \\
\text { due to a higher price level in the urban sector. }\end{array}$ \\
\hline Marginal Cost E1a & 3 & 3 & $\begin{array}{l}\text { Both have universal metering volumetric pricing } \\
\text { systems. }\end{array}$ \\
\hline Marginal Cost E1b & 2 & 1 & $\begin{array}{l}\text { Price level (for blocks and actual billed) in Jordan } \\
\text { comparatively higher but still heavily subsidized while } \\
\text { water scarcity is severe and higher than in Iran; urban } \\
\text { water price in Iran remains low despite recent increases } \\
\text { while scarcity is rapidly increasing. }\end{array}$ \\
\hline $\begin{array}{l}\text { Economic Regulation } \\
\text { E2 }\end{array}$ & 1 & 1 & $\begin{array}{l}\text { Despite benchmarking being discussed and initiated, } \\
\text { particularly in Jordan, both countries have not yet } \\
\text { implemented and institutionalized economic regulation. }\end{array}$ \\
\hline Competition E3 & 1 & 1 & $\begin{array}{l}\text { There are no water trading schemes for the urban sector } \\
\text { in both countries. }\end{array}$ \\
\hline Cost Recovery & 6 & 4 & $\begin{array}{l}\text { Jordan performs better due to more effective cost } \\
\text { recovery and increased private sector participation. }\end{array}$ \\
\hline $\begin{array}{l}\text { Financial Viability } \\
\text { C1a }\end{array}$ & 2 & 1 & $\begin{array}{l}\text { Jordan has begun to cover basic O\&M costs despite } \\
\text { recent serious challenges (e.g., demand increases, } \\
\text { refugee crisis); most utilities in Iran do not cover this } \\
\text { cost. }\end{array}$ \\
\hline $\begin{array}{l}\text { Financial Viability } \\
\mathrm{C} 1 \mathrm{~b}\end{array}$ & 2 & 2 & $\begin{array}{l}\text { Some utilities face serious challenges to cost recovery in } \\
\text { both countries, while stable enforcement mechanisms } \\
\text { indicate the national average to still be high. }\end{array}$ \\
\hline $\begin{array}{l}\text { Commercialization } \\
\mathrm{C} 2\end{array}$ & 2 & 1 & $\begin{array}{l}\text { Unlike Iran, Jordan has implemented PPPs and } \\
\text { increased private sector participation. }\end{array}$ \\
\hline Equity & 11 & 8 & $\begin{array}{l}\text { Jordan outperforms Iran on equity due to more } \\
\text { transparent tariffs and increased levels of local } \\
\text { participation. }\end{array}$ \\
\hline Affordability Q1 & 3 & 3 & $\begin{array}{l}\text { In both countries, current water bills do not exceed } \\
\text { international benchmarks for affordability. }\end{array}$ \\
\hline Accessibility Q2 & 3 & 3 & Both countries have very high services coverage. \\
\hline Transparency Q3 & 3 & 1 & $\begin{array}{l}\text { In Iran, water prices are highly differentiated with large } \\
\text { differences in price levels among tiers and } \\
\text { municipalities, while Jordan's tariff structures are more } \\
\text { transparent due to recent simplifications, and a smaller } \\
\text { number of cities and providers. }\end{array}$ \\
\hline Participation Q4 & 2 & 1 & $\begin{array}{l}\text { Jordan has implemented decentralization reforms giving } \\
\text { significant powers to some regional utilities, although } \\
\text { some regions remain under centralized services. Iran has } \\
\text { not effectively transferred financial independence } \\
\text { through decentralization. }\end{array}$ \\
\hline Total & $24 / 36$ & $18 / 36$ & \\
\hline
\end{tabular}

Regarding the relationship between the water price level and water scarcity (indicator E1b), the situation is problematic in Jordan and Iran, although Jordan has a better score due to the relatively higher price level. Jordan has an increasing block tariff with block tariffs ranging from around 0.9 USD to 3 USD per cubic meter (water and wastewater combined), plus a fixed charge ranging from 1 USD to 2.4 USD per month [66]. A national average could not be found. In comparison to global datasets, this water tariff ranges from 1.23 USD and 4.4 USD per cubic meter in OECD countries [13]. In the survey of the Global Water Intelligence (GWI) of more than 300 OECD cities, the average of combined charges was 2.0 USD per cubic meter, though the price could rise to 10 USD per cubic meter in some cities [17]. While water tariffs in Jordan might be higher than the average water tariff in the Middle East and North Africa (MENA) region of around 0.4 USD [78], the country suffers from severe water scarcity, more severe than the regional average. This severe scarcity coupled with the rapidly increasing marginal costs of water supply might therefore not be reflected in the current prices. In fact, urban water supply shortages are commonplace in major cities in Jordan. This can lead to consumers paying about 4.2 USD (3 Jordanian Dinar (JOD)) per cubic meter to private vendors (water tankers) instead of the much cheaper price to utilities of around 0.56-0.85 USD (0.4-0.6 JOD) [79]. Some studies put the tanker water price at 5.4 USD (3.85 JOD) per cubic meter [24]. At the same time, Gerlach [25] points out that, in the case of Amman, only very few surveyed consumers (3\%) pay the low price of the 
lifeline tariff [25]. The majority (46\%) pay a 3 times higher price, while some others (14\%) can pay up to 10 times higher prices. Although we cannot make a final determination on the average billed urban water price in Jordan in this paper, the relatively—in international and regional comparisons—high prices in Jordan suggest a moderate score on this indicator.

In Iran, water tariffs follow a fixed but complicated structure. The tariff ranges rather indicate low tariffs in comparison to the increasing scarcity level. As a result, the complicated multi-variable water tariff system, and many different water prices at regional level, do not lead to a significant difference in lowering water demand compared to a national water tariff. Attari and Dijk [26] put the average domestic country-level water price at 0.033 USD per cubic meter (exchange rate of December 2018) before the reform of 2011, and around 0.059 USD after the reforms, which replaced parts of the subsidies for basic services through cash transfers. However, if one uses data on total billed amounts and water volumes, the average municipal price in some provinces is higher (e.g., in Tehran). It is important to note that the water prices for the urban residential units follow the increasing block tariff, with up to 10 block tariffs ranging from around 0.04 USD to over 10 USD per cubic meter for some blocks [67]. Each city is allocated a coefficient to adjust the tariff at regional level. A water tariff for municipal uses in rural areas is $50 \%$ of the tariffs for the nearest city, and for non-municipal purposes, $100 \%$ of the nearest city. Furthermore, water tariffs in summertime (May, June, July, and August) for municipal and non-municipal uses higher than 25 cubic meters per month usually increase by $20 \%[80]$.

Finally, the remaining indicators of regulation (E2) and competition (E3) were evaluated as 'low' in both countries. Regulation is a highly political topic in water governance in Jordan, especially in light of increasing private-sector participation. Nonetheless, beyond some benchmarking projects and ad hoc standard-setting, no tariffs or incentive-based regulation mechanisms have been adopted [22]. Similarly, water markets for bulk water or agricultural transfers are not implemented despite water trading being on the agenda, particularly for the agricultural sector in regions such as the Jordan Valley [81]. In Iran, regulation of water utilities using incentives and yardsticks is not yet implemented. Finally, the implementation of water markets is seen as a part of a range of future policy solutions to tackle increasing scarcity in Iran, and is still in its planning stages [67]. Such markets are supposed to be applied for bulk water, or expand the small schemes of agricultural water transfer at local level in regions facing low water availability. Competition is thus relatively low in Iran's water sector.

\subsubsection{Cost Recovery}

In total, Jordan's water tariffs perform better on cost recovery than on efficiency, while Iran's performance is quite low on this category as well. First, let us examine price level and the cost recovery of O\&M costs (indicator $\mathrm{C} 1 \mathrm{a}$ ). In Jordan, considering the above-mentioned data on block tariff range and supply per capita, one can argue that most consumption would end up within the first two blocks: i.e., below 40 cubic meters. In fact, average daily water consumption is indicated at around 50-80 liters per person per day, according to key performance indicators for the urban water supply (see also [22]). Households consuming under 40 cubic meters per month are going to pay little more than 1 USD per cubic meter using the current block tariff formula. According to our scoring, such a price would be enough to cover O\&M costs of utilities. In fact, data from 2003-2004 and 2008 show that tariffs were enough to recover most of O\&M costs, but little of the capital costs $[70,82]$. However, capital costs have been rapidly increasing due to scarcity and the need for costly investments in alternatives. Furthermore, the Syrian refugee crisis has increased the cost of the utilities, which were required to make new investments in water supply and wastewater treatment, and therefore, according to the government, the O\&M cost recovery might be achievable by 2020 [66]. Full cost recovery is a major concern for policymakers in Jordan, with water-related subsidies making up 20\% of the government deficit in 2010 [22]. According to the National Water Strategy, 2016-2025, cost recovery of O\&M reached $100 \%$ in the past, but was $60-70 \%$ if capital costs (depreciation and recovery) are included in the calculation [68]. Moreover, the cost recovery deteriorated since 2005, mainly due to 
capital investments and the high non-revenue water levels, and hence cost-savings measures and increases in revenues, including tariffs, are under consideration [68]. Furthermore, cost recovery has been more achieved in some utilities, e.g., the Aqaba Water Company, while in other utilities, e.g., Miyahuna Water Company, revenues from water services have been unable to cover O\&M costs [22].

In Iran, cost recovery of water supply in Iran is often not feasible at the current price levels, with the average cost recovery rate through water charges being around $20 \%$ of operational cost, with better performance in larger cities such as Tehran and Isfahan [67]. Many utilities are subsidized by the government in order to cover basic operation and maintenance costs. However, city councils can ask the ministry of energy to adjust the water and sanitation service tariffs at the local level according to the water cost. In recent years, water tariffs have increased considerably, mainly due to higher water supply costs, and also to create an incentive to reduce water use in urban regions. In 2014, prices increased by around 20\% [83], while in 2015, they increased by at least $10 \%$ compared to the previous year depending on the block tariff [84]. In fact, this trend of increased prices continued, with e.g., in 2018, an estimated increase in electricity and water prices of 7\% [85]. However, the average water cost per cubic meter was about 0.4 USD, which was 3.4 times higher than the average water price of 0.11 USD per cubic meter in 2015, while the water cost continued to increase at higher percentage rates than the increases in the water prices in 2016 [86]. Urban water cost is thus undermining the pricing reforms, while the cost of water extraction for agricultural purposes is also increasing in many regions due to a reduction in the water table and the need for well deepening or reallocation [29,87].

With regard to bill collection $(\mathrm{C} 1 \mathrm{~b})$, in Jordan, the collection rate of billed water is high in Jordan but still faces problems in some areas. This is due to political problems and the failure of utilities to follow up on customers' debts [22,68]. In fact, water utilities in Jordan are already under a high financial burden due to increased abstraction costs, and they are thus highly subsidized through energy prices. In Iran, an official national average could not be found. Records exist about difficulties in some utilities with collecting bills. We thus assume a moderate indicator value, considering the strong state enforcement capabilities. Finally, with regard to commercialization (C2), Jordan has a better, but still moderate, score compared with Iran. In recent years, Jordan has embarked on reforms to promote commercialization through the 'corporatization' of public utilities and the promotion of private-sector participation (PSP). PSP is still limited to selected small-to-large-scale projects ranging from service contracts and management contracts to build-operate-transfer (BOT) projects. Such commercialization has resulted in tangible improvements in cost recovery and efficiency in both the water and wastewater sectors [22,71]. In Iran, private sector participation is generally very low, although there are scattered efforts to encourage it beyond the current private activities in the desalination and water transport sector [67].

\subsubsection{Equity}

On equity, Jordan scores rather high while Iran scores best in this category. Regarding the indicator of affordability (Q1), in Jordan, water expenditure has accounted for only around $1 \%$ of monthly household expenditure, making water services quite affordable [88]. More recent data show affordability for certain urban low-income population raising up to $3 \%$, but not exceeding the $3-5 \%$ range recommended by the World Bank [23]. In Iran, considering the average income level of an Iranian household and the average water use per household, water for municipal use can be seen as affordable, and is reported to be around 2 USD for an average four-person family [89], and based on a general price level is still among the lowest in the world [87]. For example, in a 2016 survey conducted in Mashhad city, 95\% of mostly low-income respondents viewed the price as affordable [26].

Regarding the accessibility indicator (indicator Q2), service coverage was higher than $90 \%$ in 2015 in Jordan, according to data from the WHO/UNICEF Joint Monitoring Program for Water Supply and Sanitation [90]. In Iran, in 2015, 96.2\% of the population had access to safe drinking water: $97.7 \%$ in urban and $92.1 \%$ in rural areas [69]. However, water rationing is imposed in Tehran and other big cities, especially in summertime. On transparency (indicator Q3), in Jordan, the number of water tariffs 
is limited to two: one for the Water Authority of Jordan and another for the remaining three utilities of Miyahuna, Aqaba Water Company, and Yarmouk Water Company. This results in a high score in our assessment of this indicator. In contrast, this criterion can be considered to be low in Iran due to the relatively complicated water tariff system. The government pursues a national tariff system, which is then, in theory, adapted locally to the diverse climate zones, water availability levels, and water supply sources. On the participation indicator $(\mathrm{Q} 4)$, participation through decentralization has improved in Jordan with the establishment of the water companies, which are largely independent with their own governance structures [22]. However, regions under the Water Authority of Jordan are served by a utility that is relatively centralized. Therefore, Jordan has been given a moderate score on this indicator. In Iran, participation is quite low due to the highly centralized supply system, as is also the case in other subsectors such as irrigation and groundwater management [91]. The government is the main water supplier, alongside its task of defining the water price level. In doing so, the government is obliged to consider the regional socio-economic specificity of different regions in tariff design, or to transfer tariff-setting powers to water users in the event of its inability to provide services. Provincial companies are in charge of service provision, but they do not exhibit effective financial independence. These companies, which heavily rely on subsidies, have independent financial and accounting systems but no leverage over tariff systems, while they are demanded to reimburse a percentage of their sales to the national government [67].

\subsection{Limitations of the Scorecard}

The design of the scorecard is based on a selection of determinants of sound water-pricing policies. Such determinants are derived from theoretical arguments about the objectives of water pricing presented in Chapter 2. In this sense, the scorecard focuses on the core objectives of water pricing as debated in the related literature. These objectives incorporate three perspectives: the economic (efficiency), the financial (cost-recovery), and the social (equity) perspectives, but all translated through the lens of price. For example, we discuss transparency because complicated tariff structures can be perceived by consumers as unjust, leading to multiple problems such as administration difficulty, consumers not adjusting the demand according to prices, or households refusing to pay their bills $[6,7]$. Of course, some of these problems-such as the low collection rate-can occur due to different reasons such as the state fragility or capture of water resources by elites. Since we included only the core causal relations that can be attributed to different tariff structures, we did not consider broad contextual categories such as the shape of water governance systems or performance aspects not related to the water sector.

This is true for quality aspects of water services, which represent a common category in benchmarking the performance of water utilities or the water sector altogether [92], but not in our scorecard. For example, the indicator of constancy or continuity of water supply determines whether there are interruptions in the water supply. In the Global Competitiveness Report, 2018, of the World Economic Forum, Jordan and Iran achieved scores of 66\% (66th global rank) and 57\% (85th global rank) respectively on the "reliability of water supply" indicator measuring flow fluctuations and the lack of interruptions [93]. In fact, both counties suffer from this issue with Jordan's capital, in periods of scarcity, receiving water only once a week [94], while water rationing and disruption have become a serious problem in Iran [95]. Although these problems of service quality are of major concern for the overall water sector performance, we do not recognize them as core categories of pricing performance. In fact, quality issues are related to pricing discussions embedded within broader frameworks of water security and sector performance [96].

Another limitation of the scorecard is the absence of site-specific indicators that incorporate local differences. For example, the issue of the ability of prices to incorporate full economic cost, including scarcity conditions and (environmental) externalities could not be reflected on in detail in this paper. In fact, we included some approximations for this objective through the indicators on metering and price level in comparison to scarcity. These are necessary conditions for full economic 
cost, but other calculations on negative (environmental) externalities (e.g., loss of ecosystems due to water supply), or even positive ones (e.g., health-related benefits of water supply) are necessary to determine the full economic cost. In fact, as mentioned in Chapter 2, for incorporating externalities one would need to estimate the marginal cost of water supply as a full opportunity cost, which would vary greatly from one locality to another. This paper has not done that, while it still argues-on the basis of the price level, scarcity conditions, and the incidents of water-related ecological problems-that the current prices are unlikely to cover environmental externalities in both countries.

A related issue is with regard the limited ability to generalize findings for all urban areas. In fact, the indicators of universal metering, regulation, competition, transparency, and participation relate to factors that often applies across utilities and geography, e.g., existence institutional frameworks and policies determining regulatory bodies, level of service delivery, ownership of assets, etc. However, other indicators such as cost recovery, affordability and coverage are naturally different from an area to another. While we did not analyze these urban differences, they can be significant but expectedly less severe than urban-rural differences. Concealing inequalities and geographic differences is a common limitation of any aggregated index or assessment, although, in theory, our assessment can be applied to any locality in detail in future research endeavors.

In fact, the lack of local data can be justified by the nature of the scorecard design as a national comparison to encourage structured discussions on tendencies and performances of water pricing policies. As such, it differs from benchmarking approaches that usually compare a large number of utilities using a bigger set of indicators. While our aggregated indicators included operationalization guidelines and retraceable steps, some relied on argumentative and theoretically informed reconstruction of evidence from literature and individual data points. In this sense, the scorecard provides categories of criteria or principles as entry points for sound water pricing and investigates these categories in the cases of Iran and Jordan. In fact, such an approach is advocated by some scholars as an alternative that can alleviate problems of quantitative benchmarking assessments which mainstream insights and impose universality [97].

\section{Comparison and Discussion}

Many developing nations share a common narrative with regard to the evolution of water management as an economic and environmental concern. Rising water scarcities, expanding populations and economies, high urbanization rates, and increasing external threats to water availability all increase the burden on water utilities. Both Jordan and Iran face these challenges, which make rethinking current pricing schemes an urgent matter. We have outlined the multifaceted-and often conflicting - demands on urban water pricing and identified simple indicators to make the comparative assessments of water pricing policies more accessible and better structured. The objectives and indicators presented do not provide an exhaustive list or absolute ranks, although they arguably represent major critical influence factors on urban water pricing performance based on debates among scholars and well-intentioned policymakers.

The comparison suggests that the current pricing schemes and tariff levels might be economically inefficient and financially unsustainable (i.e., for cost recovery of utilities) in light of increasing scarcity conditions, production costs, and environmental externalities. However, this conclusion is premature given the lack of detailed data and the complexity of water pricing systems. Although the national-level and comparative perspective of this paper has provided a valuable sense of the directions and challenges of urban water pricing in Jordan and Iran, the insights are difficult to generalize for all localities and utilities. Inter-country pricing analyses reveal performance tendencies such as low price and coverage levels or the primacy of the equity objective in the pricing practice of developing countries. However, pricing policies vary greatly with socio-economic and hydrological conditions, leading to the inability to rate policies in studies with a large number of cases. At the same time, it has become evident that socio-economic considerations such as affordability, welfare redistribution, or subsidizing consumers are strongly reflected in the current pricing policies. 
While policymakers in developing countries tend to emphasize affordability over other objectives of urban water pricing $[4,5,36,60]$, it is not possible to show with certainty whether subsidies of water services still correspond to today's poverty patterns, or if they are able to specifically target poor areas. Often, pricing policies to promote water use date back to post-World War II and post-independence developmental strategies, when neither the concept of integrated and sustainable water management nor that of demand management were developed. Worldwide, full-cost pricing, or even simple financial self-sufficiency, is rarely met in the majority of utilities in developing countries, as the GWI's water pricing survey indicates $[15,17]$. This survey also shows that water prices are rising globally and that higher prices often correspond to better governance and decreased risk of water shortages (i.e., lower consumption and higher investments in reliability of services). The World Bank [98] shows the same shortcomings of water pricing in the MENA region, emphasizing the political difficulty of reforming such prices, which largely positively correlate with the energy production level of a country. In our cases, recent pricing reforms in the two countries show the intention to make water prices more effective. In total, Iran performed worse than Jordan on efficiency and cost recovery.

Comparative, in-depth assessments such as the one proposed in this paper provide insights about best practices while still being able to appraise the overall pricing performance. In our analysis, Jordan's water tariffs seem to perform better than Iran's due mainly to two factors. Firstly, Jordan has introduced reforms that aim at improving cost recovery through higher prices and increased participation. Evidence presented earlier indicates that commercialization of water utilities and a range of instruments for private-sector participation have recently resulted in better financial and economic performance. Still, in the light of rapidly increasing abstraction costs and the need to expand services, pricing performance in Jordan is not high with regard to efficiency and full cost recovery. Iran, in contrast, has only recently discovered the leverage provided by adjusting water prices.

Secondly, Iran has very complicated tariff systems, evident in the earlier-mentioned large number of providers and tariffs. This can impede transparency, while the effective independence of regional and local providers is hindered by the reliance on the government's subsidies and guidance with regard to tariff setting [67]. It is important to keep in mind that Iran is 10 times bigger than Jordan in terms of population and has a much more complicated surface and groundwater systems. In this sense, it seems easier for Jordan to introduce simple tariffs, decentralize, and maintain oversight. It is therefore legitimate to ask whether it would have been better to compare urban settings only; e.g., comparing Jordan's capital Amman to Tehran, the capital of Iran. However, Tehran is still almost three times larger in population. Furthermore, such a comparison of water pricing in cities using our assessment be carried out in future research although it will still remain difficult, if not impossible, to find objectively perfect matches across countries. Considering the aim of this research to provide a macro-level view, such a view is justified as it is imperative for policymakers to be able to gain a perspective on the performance of water pricing on a national level and identify reform areas. While reform actions can take place locally, water resources still need be assessed on a macro level in terms of similarities and discrepancies between scarcity levels and thresholds, environmental pressures, security, or economic and sustainable utilization.

\section{Conclusions}

Urban water pricing as an instrument to encourage overall sustainable resource utilization is most often a topic of academic scholarship. Politicians and decision-makers might choose to avoid the complex and controversial issue of pricing public services such as water. At the same time, better prices can accommodate for the investments needed to cover rising production costs and the required fixed costs of expanding the services to cover growing populations and industries. Rising physical scarcity in the MENA region represents a strong impetus for reforming subsidized and inefficient pricing structures. Much can be gained by exchanging regional practices and benchmarking pricing performance across different cases. While there is much evidence of the underperformance of water 
prices in many developing regions, and the required tariff adjustments, there is a lack of comparative tools to help with prioritizing policy and providing signals for decision-makers.

The scorecard proposed by this paper can be applied at different scales from local to national. It captures the various pricing principals and demands on good tariffs while offering a method of assessing them through the comparison of scarcity, cost conditions, and international practices. By comparing Jordan and Iran, we have shown that water pricing is a cross-sectoral and multi-dimensional policy issue. Facing pressures from donors and increasing shortages, Jordan was able to initiate reforms to increase participation and financial viability of utilities. In comparison, Iran is starting to reform its pricing practice. While the current tariff structure is complex and focused on accommodating local conditions through coefficients and use proxies, it is still not effective at curbing demand and recovering basic costs.

The pricing policies in both Iran and Jordan did not achieve a high overall score due to their shortcomings on economic efficiency and cost recovery. The national policies of both countries remain oriented towards affordability of services, agricultural subsidies, and maintaining a strong public role in supply and control of water services. Jordan's experience of corporatization and regionalization of supply services could be interesting for Iran to study. Iran's centralized planning approach to water services is not well-ranked with regard to efficient and cost-adequate prices. A regional, decentralized approach such as that of Jordan might be more transparent and capable of incorporating changes in climate conditions and costs structures into water tariffs. This, however, requires detailed consideration and further research.

There are some important opportunities for mutual learning provided by the comparative pricing assessment. The proposed tool can encourage more case studies from the region, or beyond, in order to advance the highly neglected topic of water prices. Similar to assessing overarching public or developmental policies across countries, there is a need to monitor and assess a country's ability to encourage the use of water as an economic and a scarce good. It is a responsibility of national policies to set standards and mechanisms for efficient and sustainable water use and to protect the highly vulnerable water resources. Water pricing is a part of this, and the current policies in the urban sector exhibit some shortcomings. For example, as in many other developing countries, Iran and Jordan are yet to introduce effective and independent sector regulation that can utilize price assessments. Besides this, data availability is a still a major problem hindering detailed analyses. Furthermore, future reforms can enable utilities to set the correct local tariff design that accommodates the multiple technical and socio-economic objectives of water pricing policies. For this, institutional capacity and a level of independence might be required, but also incentives for good performance of utilities regarding their pricing and cost-recovery policies.

Author Contributions: Conceptualization, M.A.-S. and S.D.; Methodology, M.A.-S. and S.D.; Formal analysis, M.A.-S. and S.D.; Investigation, M.A.-S. and S.D.; Resources, M.A.-S. and S.D.; Data curation, M.A.-S. and S.D.; Writing-original draft preparation, M.A.-S. and S.D.; Writing—review and editing, M.A.-S. and S.D.; Visualization, M.A.-S.

Funding: The publication of this article was funded by the Qatar National Library.

Conflicts of Interest: The authors declare no conflict of interest.

\section{References}

1. Rogers, P.; Silva, R.D.d.; Bhatia, R. Water is an economic good: How to use prices to promote equity efficiency and sustainability. Water Policy 2002, 4, 1-17. [CrossRef]

2. Banerjee, S.; Foster, V.; Ying, Y.; Skilling, H.; Wodon, Q. Cost Recovery, Equity, and Efficiency in Water Tariffs: Evidence from African Utilities; The World Bank: Washington, DC, USA, 2010.

3. Loehman, E.T. Cost Recovery, Efficiency, and Economic Organization for Water Utilities. Contrib. Econ. Anal. Policy 2004, 3, 181. [CrossRef]

4. Rhodes, G.F; Sampath, R.K. Efficiency, Equity and Cost Recovery Implications of Water Pricing and Allocation Schemes in Developing Countries. Cana. J. Agric. Econ./Reoue Cana. D'agroecon. 1988, 36, 103-117. [CrossRef] 
5. Al-Saidi, M. Urban water pricing in Yemen: A comparison of increasing block tariffs to other pricing schemes. Water Int. 2017, 42, 308-323. [CrossRef]

6. Dinar, A. Policy implications from water pricing experiences in various countries. Water Policy 1998, 1, 239-250. [CrossRef]

7. Dinar, A.; Subramanian, A. Water Pricing Experiences: An International Perspective; The World Bank Group: Washington, DC, USA, 1997.

8. Dinar, A. The Political Economy of Water Pricing Reforms; Oxford University Press: New York, NY, USA, 2000.

9. Cornish, G.; Bosworth, B.; Perry, C.J.; Burke, J.J. Water Charging in Irrigated Agriculture: An Analysis of International Experience; Food and Agriculture Organization of the United Nations: Rome, Italy, 2004.

10. Dinar, A.; Mody, J. Irrigation water management policies: Allocation and pricing principles and implementation experience. Nat. Resour. Forum 2004, 28, 112-122. [CrossRef]

11. Tsur, Y.; Roe, T.L.; Doukkali, R.; Dinar, A. Pricing Irrigation Water: Principles and Cases from Developing Countries; Resources for the Future: Washington, DC, USA, 2004.

12. Nauges, C.; van den Berg, C. Heterogeneity in the Cost Structure of Water and Sanitation Services: A Cross-country Comparison of Conditions for Scale Economies. Oxf. Dev. Stud. 2010, 38, 199-217. [CrossRef]

13. Organisation for Economic Co-Operation and Development (OECD). Pricing Water Resources and Water and Sanitation Services; OECD Publishing: Paris, France, 2010.

14. Dinar, A.; Pochat, V.; Albiac, J. Water Pricing Experiences and Innovations; Springer: Cham, Switzerland, 2015.

15. Zetland, D.; Gasson, C. A global survey of urban water tariffs: Are they sustainable, efficient and fair? Int. J. Water Resour. Dev. 2013, 29, 327-342. [CrossRef]

16. Organisation for Economic Co-operation and Development (OECD). The Price of Water: Trends in OECD Countries; OECD: Paris, France, 1999.

17. Global Water Intelligence (GWI). GWI OECD Global Water Tariff Survey; Global Water Intelligence (GWI): Oxford, UK, 2011.

18. Global Water Intelligence (GWI). The Global Water Tariff Survey; Global Water Intelligence (GWI): Oxford, UK, 2018.

19. BLACK \& VEATCH. 50 Largest Cities Water/Wastewater Rate Survey; BLACK \& VEATCH: Overland Park, KS, USA, 2013.

20. World Bank. The World Bank Data; World Bank: Washington, DC, USA, 2019; Available online: https: / / data.worldbank.org/ (accessed on 1 January 2019).

21. Schyns, J.; Hamaideh, A.; Hoekstra, A.; Mekonnen, M.; Schyns, M. Mitigating the Risk of Extreme Water Scarcity and Dependency: The Case of Jordan. Water 2015, 7, 5705-5730. [CrossRef]

22. Organisation for Economic Co-operation and Development (OECD). Water Governance in Jordan; Overcoming the Challenges to Private Sector Participation; Organisation for Economic Co-operation and Development (OECD): Paris, France, 2014.

23. Klassert, C.; Sigel, K.; Klauer, B.; Gawel, E. Increasing Block Tariffs in an Arid Developing Country: A Discrete/Continuous Choice Model of Residential Water Demand in Jordan. Water 2018, 10, 248. [CrossRef]

24. Klassert, C.; Sigel, K.; Gawel, E.; Klauer, B. Modeling Residential Water Consumption in Amman: The Role of Intermittency, Storage, and Pricing for Piped and Tanker Water. Water 2015, 7, 3643-3670. [CrossRef]

25. Gerlach, E.; Franceys, R. Regulating water services for the poor: The case of Amman. Geoforum 2009, 40, $431-441$. [CrossRef]

26. Attari, J.; van Dijk, M.P. Reaching the poor in Mashhad City: From subsidising water to providing cash transfers in Iran. IJW 2016, 10, 213. [CrossRef]

27. Ardalan, A.; Khaleghy Rad, M.; Hadi, M. Urban Water Issues in the Megacity of Tehran. In Urban Drought: Emerging Water Challenges; Asia; Ray, B., Shaw, R., Eds.; Springer: Singapore, 2019; pp. 263-288.

28. Yazdandoost, F. Dams, Drought and Water Shortage in Today's Iran. Iran. Stud. 2016, 49, 1017-1028. [CrossRef]

29. Madani, K.; AghaKouchak, A.; Mirchi, A. Iran's Socio-economic Drought: Challenges of a Water-Bankrupt Nation. Iran. Stud. 2016, 49, 997-1016. [CrossRef]

30. Whittington, D. Tariffs and Subsidies in South Asia: Understanding the Basics; World Bank: Washington, DC, USA, 2002.

31. Warford, J.J. Marginal Opportunity Cost Pricing for Municipal Water Supply; International Development Research Center: Ottawa, ON, Canada, 1997. 
32. Mathur, O.P.; Thakur, S. Urban Water Pricing: Setting the Stage for Reforms; National Institute of Public Finance and Policy: New Delhi, India, 2003.

33. Tsur, Y.; Dinar, A. Efficiency and Equity Considerations in Pricing and Allocating Irrigation Water; World Bank: Washington, DC, USA, 1995.

34. Ojha, R.; Thapa, B.; Shrestha, S.; Shindo, J.; Ishidaira, H.; Kazama, F. Water Price Optimization after the Melamchi Water Supply Project: Ensuring Affordability and Equitability for Consumer's Water Use and Sustainability for Utilities. Water 2018, 10, 249. [CrossRef]

35. Dahan, M.; Nisan, U. Unintended consequences of increasing block tariffs pricing policy in urban water. Water Resour. Res. 2007, 43. [CrossRef]

36. Smith, L.; Hanson, S. Access to Water for the Urban Poor in Cape Town: Where Equity Meets Cost Recovery. Urban Stud. 2003, 40, 1517-1548. [CrossRef]

37. García-valiñas, M.A. Efficiency and Equity in Natural Resources Pricing: A Proposal for Urban Water Distribution Service. Environ. Resour. Econ. 2005, 32, 183-204. [CrossRef]

38. Moilanen, M.; Schulz, C.-E. Water pricing reform, economic welfare and inequality. South Afr. J. Econ. Manag. Sci. 2002, 5, 354-378.

39. Scanlon, J.; Cassar, A.; Nemes, N. Water as a Human Right? IUCN Publications: Gland, Switzerland; Cambridge, UK, 2006.

40. Bakker, K.J. Paying for Water: Water Pricing and Equity in England and Wales. Trans. Inst. Br. Geogr. 2001, 26, 143-164. [CrossRef]

41. Hadadin, N.; Qaqish, M.; Akawwi, E.; Bdour, A. Water shortage in Jordan-Sustainable solutions. Desalination 2010, 250, 197-202. [CrossRef]

42. Barrett, R.; Sinclair, P. Water Charges and the Cost of Metering; Discussion Papers 99-05; Department of Economics, University of Birmingham: Birmingham, UK, 1999.

43. Chambouleyron, A. Optimal Water Metering and Pricing. Water Resour. Manag. 2004, 18, 305-319. [CrossRef]

44. Freebairn, J. Some emerging issues in urban water supply and pricing. Econ. Pap. J. Appl. Econ. Policy 2008, 27, 184-193. [CrossRef]

45. Berg, S.; Marques, R. Quantitative studies of water and sanitation utilities: A benchmarking literature survey. Water Policy 2011, 13, 591-606. [CrossRef]

46. Berg, S. Water Utility Benchmarking; IWA Publishing: London, UK, 2010.

47. Chong, H.; Sunding, D. Water Markets and Trading. Annu. Rev. Environ. Resour. 2006, 31, 239-264. [CrossRef]

48. Sibly, H.; Tooth, R. Bringing competition to urban water supply. Aust. J. Agric. Resour. Econ. 2008, 52, $217-233$. [CrossRef]

49. Agrawal, A.; Ribot, J. Accountability in Decentralization: A Framework with South Asian and West African Cases. J. Dev. Areas 1999, 33, 473-502.

50. Global Water Intelligence (GWI). Tariffs: Half Way There; Global Water Intelligence: Oxford, UK, 2004.

51. Banerjee, S.; Wodon, Q.; Diallo, A.; Pushak, T.; Uddin, H.; Tsimpo, C.; Foster, V. Access, Affordability and Alternatives: Modern Infrastructure Services in Africa; World Bank: Washington, DC, USA, 2008.

52. Hoque, S.F.; Wichelns, D. State-of-the-art review: Designing urban water tariffs to recover costs and promote wise use. Int. J. Water Resour. Dev. 2013, 29, 472-491. [CrossRef]

53. Reynaud, A. Assessing the impact of full cost recovery of water services on European households. Water Resour. Econ. 2016, 14, 65-78. [CrossRef]

54. Borrego-Marín, M.M.; Gutiérrez-Martín, C.; Berbel, J. Estimation of Cost Recovery Ratio for Water Services Based on the System of Environmental-Economic Accounting for Water. Water Resour. Manag. 2016, 30, 767-783. [CrossRef]

55. Davis, J. Private-sector participation in the water and sanitation sector. Annu. Rev. Environ. Resour. 2005, 30, 145-183. [CrossRef]

56. Prasad, N. Privatisation Results: Private Sector Participation in Water Services After 15 Years. Dev. Policy Rev. 2006, 24, 669-692. [CrossRef]

57. Fankhauser, S.; Tepic, S. Can poor consumers pay for energy and water? An affordability analysis for transition countries. Energy Policy 2007, 35, 1038-1049. [CrossRef]

58. Whittington, D. Possible adverse effects of increasing block water tariffs in developing countries. Econ. Dev. Cult. Chang. 1992, 41, 75-87. [CrossRef]

59. Whittington, D. Municipal water pricing and tariff design: A reform agenda for South Asia. Water Policy 2003, 5, 61-76. [CrossRef] 
60. Whittington, D.; Hanemann, W.M.; Sadoff, C.; Jeuland, M. The Challenge of Improving Water and Sanitation Services in Less Developed Countries. MIC 2009, 4, 469-609. [CrossRef]

61. Wait, I.W.; Petrie, W.A. Comparison of water pricing for publicly and privately owned water utilities in the United States. Water Int. 2017, 42, 967-980. [CrossRef]

62. Owusu-Mensah, I. The Poor Paying for the Rich: The Politics of Inequality in the Water-Pricing Structure in Ghana, 2003-2013. Africa Today 2017, 64, 49. [CrossRef]

63. Crook, R.C.; Manor, J. Democracy and Decentralisation in South Asia and West Africa: Participation, Accountability, and Performance; Cambridge University Press: Cambridge, UK, 1998.

64. Manor, J. The Political Economy of Democratic Decentralization; The World Bank: Washington, DC, USA, 1999.

65. Smoke, P. Fiscal Decentralization in Developing Countries: A Review of Current Concepts and Practice; UNRISD: Geneva, Switzerland, 2001.

66. Ministry of Water and Irrigation (MWI). Structural Benchmark-Action Plan to Reduce Water Sector Losses; Ministry of Water and Irrigation (MWI): Amman, Jordan, 2016.

67. Ministry of Energy. National Water and Waste Water Engineering Company. In The Data Collection Survey on Water Supply Sector in the Islamic Republic of Iran; Nihon Suido Consultants Co., Ltd., Islamic Republic of Iran: Tehran, Iran, 2016.

68. Ministry of Water and Irrigation (MWI). National Water Strategy of Jordan 2016-2025; Ministry of Water and Irrigation (MWI): Amman, Jordan, 2016.

69. FAO Food and Agriculture Organization of the United Nations. AQUASTAT-Main Database; 2019. Available online: http:/ / www.fao.org/aquastat/en/ (accessed on 10 January 2019).

70. USAID. Pricing of Water and Wastewater Services in Amman and Subsidy Options: Conceptual Framework, Recommendations and Pricing Model; USAID: Washington, DC, USA, 2009.

71. Al-Assa'd, T.; Sauer, J. The performance of water utilities in Jordan. Water Sci. Technol. J. Int. Assoc. Water Pollut. Res. 2010, 62, 803-808. [CrossRef]

72. United Nations. World Population Prospects, Key Finding and Advance Tables; United Nations: New York, NY, USA, 2015.

73. Abbaspour, K.C.; Faramarzi, M.; Ghasemi, S.S.; Yang, H. Assessing the impact of climate change on water resources in Iran. Water Resour. Res. 2009, 45. [CrossRef]

74. Ghasemi, A.R. Changes and trends in maximum, minimum and mean temperature series in Iran. Atmos. Sci. Lett. 2015, 16, 366-372. [CrossRef]

75. Charkhestani, A.; Salehi Ziri, M.; Amini Rad, H. Wastewater reuse: Potential for expanding Iran's water supply to survive from absolute scarcity in future. J. Water Reuse Desalin. 2016, 6, 437-444. [CrossRef]

76. USAID. Communication Strategy for Achieving Behavioral and Policy Changes in the Water, Energy and Environment Sectors, Public Action for Water, Energy and Environment Project-Prosperity, Livelihoods and Conserving Ecosystems; USAID: Washington, DC, USA, 2011.

77. Daoud, R.; Naber, H.; Abu Tarbush, M.; Quossous, R.; Salman, A.; Karablieh, E. Environmental Issues of Water Resources. In Water Resources in Jordan: Evolving Policies for Development, the Environment, and Conflict Resolution; Munther, J., Haddadin, M.J., Eds.; Resources for the Future: Washington, DC, USA, 2006; pp. 88-115.

78. Komives, K.; Foster, V.; Halpern, J.; Wodon, Q.; Abdullah, R. Water, Electricity, and the Poor: Who Benefits from Utility Subsidies? World Bank: Washington, DC, USA, 2005.

79. Kis, A.; Abdulla, F.; Abu Qdais, H.; Ungvári, G. Water Demand Management in the Context of Water Services-Jordan; Regional Environmental Center for Central and Eastern Europe (REC): Szentendre, Hungary, 2016.

80. How to Invest in Iran. Utility Rates in Iran. 2016. Available online: http:/ / www.howtoinvestiniran.com/ utility-rates-in-iran/ (accessed on 20 January 2019).

81. Molle, F.; Venot, J.-P.; Hassan, Y. Irrigation in the Jordan Valley: Are water pricing policies overly optimistic? Agric. Water Manag. 2008, 95, 427-438. [CrossRef]

82. Mohamed, A.S.; Jagannathan, N.V. Egypt: Water Sector Public Expenditure Review. In Water in the Arab World: Management Perspectives and Innovations; World Bank: Washington, DC, USA, 2009; pp. 37-58.

83. Sanati, C. In Iran, Sharp Price Increases Deliver Painful Blow. Fortune 2014. Available online: http:/ / fortune.com/ 2014/03/21/in-iran-sharp-price-increases-deliver-painful-blow/ (accessed on 14 December 2018).

84. Financial Tribune. Water Tariffs to Rise. Financial Tribune 2015. Available online: https:/ / financialtribune. com/articles/energy/26970/water-tariffs-to-rise (accessed on 12 January 2019). 
85. Financial Tribune. Hike in Water, Electricity Tariffs Ratified. Financial Tribune 2018. Available online: https: / / financialtribune.com/articles/energy/85683/hike-in-water-electricity-tariffs-ratified (accessed on 12 January 2019).

86. Iran News Agency. تومان؛ قيمت تمام شده آب بها . Iran News Agency 2017. Available online: http:/ / www.iribnews.ir/fa/news/94809/\%DB\%B1\%DB\%B2\%DB\%B0\%DB\%B0-\%D8\%AA\%D9\%88\% D9\%85\%D8\%A7\%D9\%86-\%D9\%82\%DB\%8C\%D9\%85\%D8\%AA-\%D8\%AA\%D9\%85\%D8\%A7\%D9\%85\%D8\%B4\%D8\%AF\%D9\%87-\%D8\%A2\%D8\%A8-\%D8\%A8\%D9\%87\%D8\%A7 (accessed on 6 February 2019).

87. World Bank. Iran Economic Monitor: Oil-Driven Recovery; World Bank: Washington, DC, USA, 2017.

88. USAID. Jordan Fiscal Reform Project II; Water Public Expenditure Perspectives Working Paper; USAID: Washington, DC, USA, 2011.

89. Iran Front Page News. Increase in Water Price May Help Iran Overcome Drought 2016. Available online: https:/ /ifpnews.com/news/society/environment/increase-water-price-may-help-iranovercome-drought/ (accessed on 4 January 2019).

90. UNICEF/WHO Joint Monitoring Programme for Water Supply and Sanitation. WASH Data, 2019. Available online: https: / washdata.org/ (accessed on 7 January 2019).

91. Nabavi, E. Failed Policies, Falling Aquifers: Unpacking Groundwater Overabstraction in Iran. Water Altern. 2018, 11, 699-724.

92. Cabrera, E.; Danke, P.; Haskins, S.; Theuretzbacher-Fritz, H. Benchmarking Water Services: Guiding Water Utilities to Excellence; IWA Pub: London, UK, 2011.

93. Global Economic Forum. The Global Competitiveness Index 4.0 Dataset: Version 20181013; Global Economic Forum: Cologny, Switzerland, 2018.

94. Trew, B. Dead Seas: How a Water Crisis in Jordan Could Threaten Middle East Peace. Independent 2018. Available online: https:/ / www.independent.co.uk/news/world/middle-east/jordan-water-crisis-israelrelationship-middle-east-peace-security-a8596621.html (accessed on 12 March 2019).

95. Tehran Times. Water Crisis in Iran: A Desperate call for Action. Tehran Times 2016. Available online: https:/ / www.tehrantimes.com/news/301198/Water-crisis-in-Iran-A-desperate-call-foraction (accessed on 12 March 2019).

96. Soto Rios, P.C.; Deen, T.A.; Nagabhatla, N.; Ayala, G. Explaining Water Pricing through a Water Security Lens. Water 2018, 10, 1173. [CrossRef]

97. McDonald, D.A. The weight of water: Benchmarking for public water services. Environ. Plan. A 2016, 48, 2181-2200. [CrossRef]

98. World Bank. Making the Most of Scarcity: Accountability for Better Water Management Results in the Middle East and North Africa; World Bank: Washington, DC, USA, 2007. 